Burial customs, the afterlife and pollution

\title{
BURIAL CUSTOMS, THE AFTERLIFE AND THE POLLUTION OF DEATH IN ANCIENT GREECE
}

\begin{abstract}
Funerary practices in ancient Greece were influenced by contemporary views on the afterlife and by concepts of pollution, but also by a desire to limit costs and a need to prevent the process of burial from causing inconvenience to the community or providing an opportunity for exploitation by those with ulterior political motives. Plato (Hippias Maior 291d and e) defined the ideal of any Greek as to be rich, healthy and honoured; to live to a grand old age; to bury his parents with honour, and ultimately to be buried in turn by his own children with due respect. This study investigates the views on disposing of the dead which were prevalent from the $8^{\text {th }}$ to the $4^{\text {th }}$ century BC in Greece, and in Attica in particular. The sources consulted include Homer's epic poems, archaeological data and vase paintings, as well as the writings of later historians, philosophers and other prominent people.
\end{abstract}

\section{THE VIEW OF THE AFTERLIFE}

There was never complete Pan-Hellenic uniformity on the concept of the hereafter, or more specifically Hades, but there were reasonably widely accepted mainstream thoughts and theories which reveal a clear line of development from the time of Homer to the Classical era (Garland 1985:1-12). Although there were thus divergent views on the immortality of the soul and related issues, particularly during the Classical era (Kurtz \& Boardman 1971:330-3), the prevailing view on the existence of the hereafter may be outlined as follows.

During the moment of death, the soul (psuche) leaves the body via the mouth or, if appropriate, via an open war wound. According to Homer other elements, namely the thumos (from the heart) and the vital spirit (aion) in the case of young people, also escape from the body but play no further role. The corpse which remains simply decomposes and is of no further importance (Sourvinou-Inwood 1995:61-3, 323-330). 


\section{HADES}

From the Odyssey, which dates from the late $8^{\text {th }}$ century BC, we learn that Hades is a dark, subterranean place (Od. 11.18-19). All human beings were believed to be mortal, although there was a single exception: King Menelaos, who appears to have been transported directly to Elysium without dying (Hom. Od. 3.236-8; 4.561-5).

One could take various routes to Hades, for instance by travelling through dark subterranean passages, or by sailing far to the west and over the edge of Okeanos (the Western Sea), which encircled the world. Hades was also encircled by water, which was at times described as a sea (Okeanos), at times as rivers. The Styx was the most famous of these, but there were also the Acheron, the Cocytus and the Puriphlegethon (Hom. Od. 10.501-2; Sourvinou-Inwood 1995:56-63). On arrival at Hades, the soul would be prevented from crossing the water before its body had been buried - the souls within would instruct it to wait in the neutral territory across the water. Hades would eventually be entered by a gate where the many-headed canine monster Cerberus kept watch, devouring any beings which attempted to leave (Hesiod Theogony $767-$ 75; Sourvinou-Inwood 1995:106-7, 309).

Within Hades, the soul lived a neutral, undifferentiated shadowexistence, without personal characteristics or understanding. There was no reward or punishment for earthly action, and no contact with the living (Hom. Od. 11.476; Garland 1985:1-2).

However, Sourvinou-Inwood (1995:66-70) has shown that the Homeric epics contain certain contradictions about the nature of the Underworld. She suggests that Homer initially collated the original tales from the pre-Homeric era, but that there had been certain alterations even in his own time; that the early and the later components of the poems therefore do not reflect the opinions of a single era, and that certain texts, such as book 24 of the Odyssey, were written later, during the archaic era (Sourvinou-Inwood 1995:94-103). The Homeric poems (even apart from $\mathrm{Od}$. 24) thus provide examples of souls in Hades which do recognise one another $(\mathrm{Od}$. 11.542-67), of the development of hierarchies (Od. 11.489-91), of the punishment of transgressors (Iliad 3.276-80; 19.359-60; Od. 11 passim), and even of Odysseus visiting Hades to contact his old friends $(\mathrm{Od}$. 11.485-6). Souls in Hades are 
Burial customs, the afterlife and pollution

also aware of friendly or inimical rituals performed at their graves (Garland 1985:4). It has also been contended that the concept of Elysium (Paradise) is not Minoan in origin, but may be ascribed to Homer (Sourvinou-Inwood 1995:32-56).

In the Archaic era (from the $8^{\text {th }}$ to the $6^{\text {th }}$ century $\mathrm{BC}$ ) the concept of the afterlife underwent a significant change. Two accompanying figures (psuchopompoi) emerge at this time, with the function of taking the soul to Hades.

According to the Odyssey (24.98-100), Hermes (he also had the cultnames Kullenios and Chthonion), the messenger of the gods, now receives the souls of the dead from Thanatos, the agent of death, and, bearing his staff (kerukeion), accompanies them along an established route to the Underworld. A soul may now enter Hades even before its body has been buried, but is only completely integrated after the burial. Hermes is the only god who may descend to the Underworld (Sourvinou-Inwood 1995:103-6).

The boatman Charon appears on the scene at a later period than Hermes. He is not mentioned in books 11 and 24 of the Odyssey, and probably derives from the (lost) epic tale of Minuas from the late $7^{\text {th }}$ century BC. Charon ferries the souls delivered to him by Hermes across the water (the river Acheron or Styx, or the lake Acherousia) to Hades (Fig. 6), where Cerberus continues to guard the entrance (SourvinouInwood 1995:303-320).

Within Hades the souls are no longer undifferentiated, insightless beings; they now know what is happening in the land of the living. Heroes are now reverenced and there is punishment for certain transgressions of life (e.g. oath-breaking). Souls can communicate with one another, although this usually requires the drinking of sacrificial blood (Hom. Il. 24.591-5; Od. 11.35-43). Garland (1985:10) describes Hades as gradually becoming a more pleasant place, with the distance between the dead and the living decreasing. No longer must all men die; some are taken directly to Elysium without passing through Hades (Sourvinou-Inwood 1995:106-7).

In the Classical era (the $5^{\text {th }}$ and $4^{\text {th }}$ centuries $\mathrm{BC}$ ), the role of the psuchopompoi is extended. Hermes does not merely accompany souls to Hades, but sometimes facilitates their temporary return to the living. 


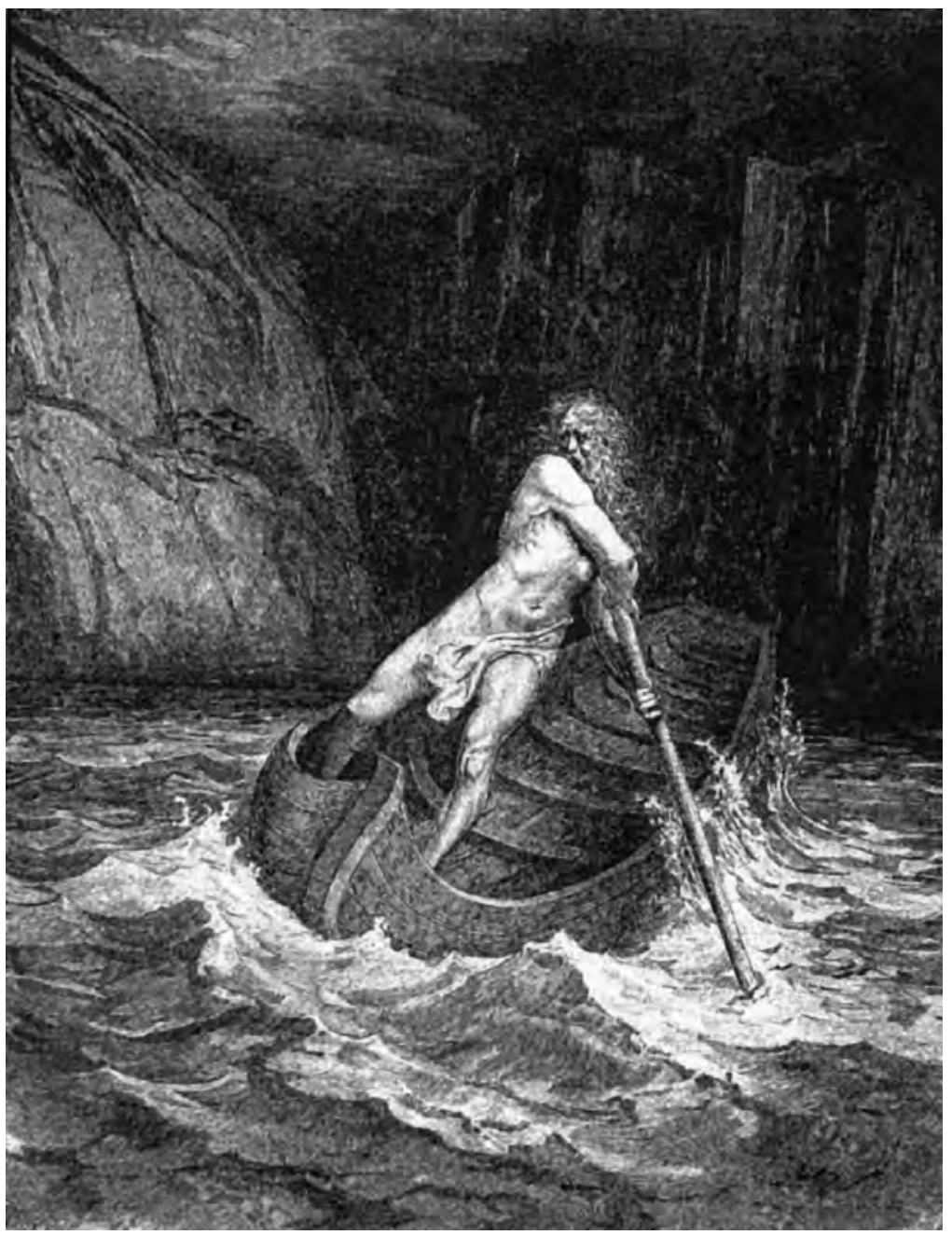

Figure 6: Charon in his boat on the river Styx.

Wood engraving by G. Doré (1860) illustrating Dante's Inferno. 
He also operates as a go-between (kêruks), sensitising souls to messages from the living (Sourvinou-Inwood 1995:304-5). Necromancy begins to flourish (Garland 1985:3) and the use of katadesmoi develops. These were tablets inscribed with curses, placed in graves so that the dead would cast curses from the Underworld upon the living (Garland 1985: 6). From 500 BC Charon's image appears regularly on vases placed beside graves (Sourvinou-Inwood 1995:321-4). The tradition of placing a coin ( $o b o l)$ in the mouth of the deceased, for Charon's fee, is a relatively late development; the earliest literary reference to it is in the Frogs of Aristophanes (line 140) (Garland 1985:23).

The concept of Elysium (Paradise) develops significantly in the $5^{\text {th }}$ and particularly in the $4^{\text {th }}$ century $\mathrm{BC}$, and is associated with the formation of religious groups (Garland 1985:18; Sourvinou-Inwood 1995:424-5). Initially, the chosen who did not die were believed to be transported directly to Elysium, but much later the view emerges that a tribunal of "judges" (Rhadamanthus, Minos or Triptolemus and Aeacus) (Fig. 7) would pronounce sentence on all souls in Hades, sending the just to Elysium but condemning the rest to punishment in the part of Hades known as Tartarus (Morford \& Lenardon 1995:295).

\section{THE POLLUTION OF DEATH}

The idea that death (like birth) involved a form of cultural/religious contamination for those involved was general in the ancient world, although its precise scope varied from area to area and from time to time. This contamination was not based primarily on considerations of hygiene, but on the view that the act was repulsive to the gods. Thus births and deaths were not permitted in holy places such as temples, or on the island of Delos. Precisely how such contamination affected individuals is not always clear, but it was believed to prevent their contact with the gods until the appropriate purification had been undergone. Pollution was also believed to apply to a period of mourning. The correct procedure for dealing with it was, in part, a matter of law (Parker 1985:32-4). (The complex origin of the concept of pollution will be addressed below.)

The house (or equivalent area) affected by a death was regarded as polluted. Water in the house was automatically contaminated, as was 


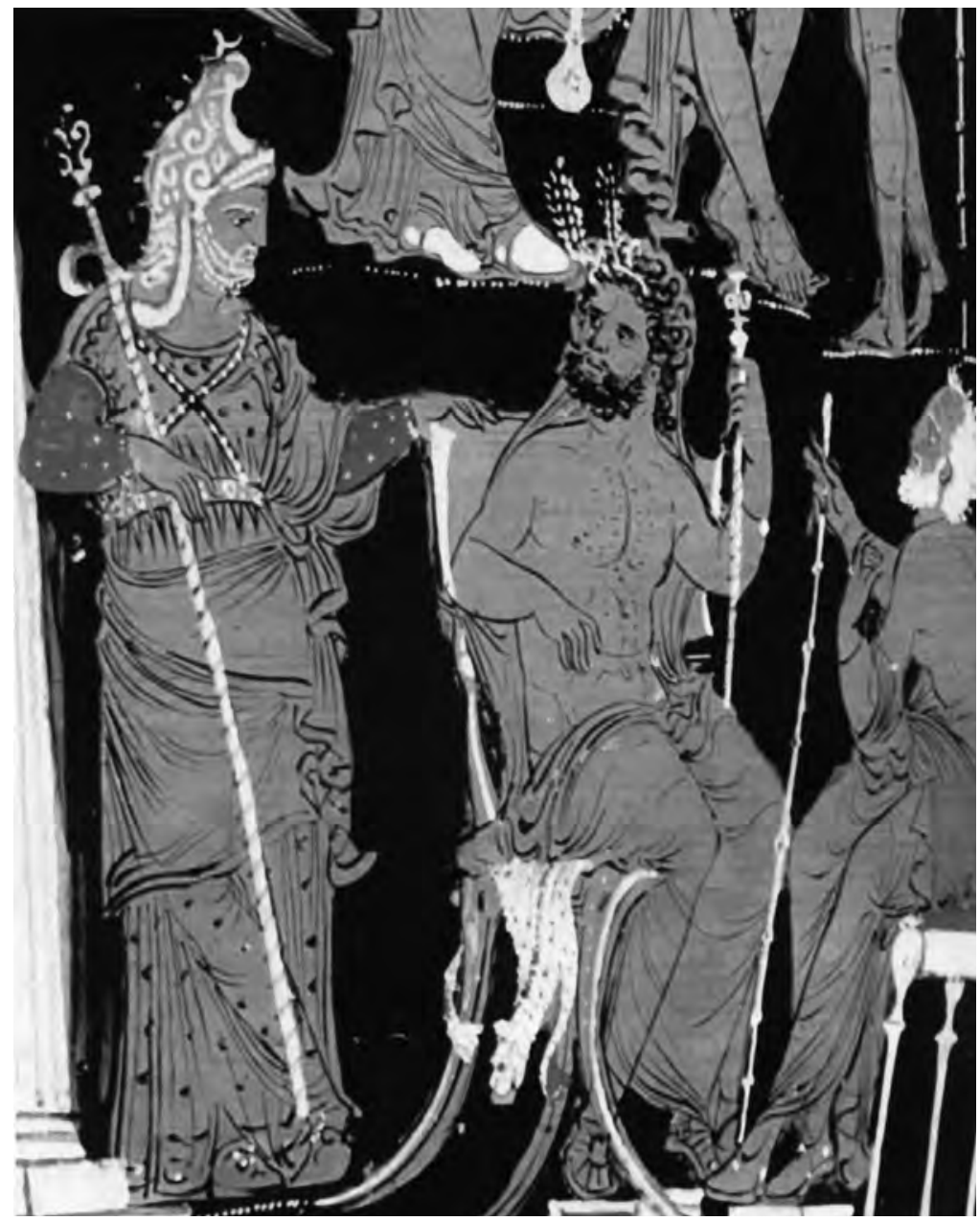

Figure 7: The three judges of the Underworld: Rhadamanthus, Triptolemus and Aeacus.

Apulian vase, $4^{\text {th }}$ century B.C. Staatliche Antikensammlungen, Munich. 
the fireplace in certain regions. When a death occurred on the street, that whole zone of the city had to be purified (Demosthenes Against Macartatus 43.51-8; Parker 1983:35-8).

Everyone touching a corpse or entering a house in which there had been a death was contaminated, as were all those who touched them. Certain close family members (as stipulated in the law) were automatically affected (Parker 1983:38-40). At one time, when a king of Sparta died, each household was expected to identify a man and a woman as contaminated by the death (Her. Hist. 6.58.1). Deceased strangers, slaves and children caused less pollution, and a dead baby could only contaminate if it were fully formed (Parker 1983:41-2; Marshall 2000: $9,10,15)$. Heroes, founders of communities and soldiers who died on the battlefield caused little or no pollution. This was also the case, surprisingly enough, with executed criminals (Marshall 2000:12, 13; Parker 1983:42, 46).

Graves (other than those of heroes) caused little pollution, but the bones and relics of the dead could contaminate. Feasts for the dead, such as the Anthesteria (which the deceased were traditionally believed to attend) could be a source of minor pollution (Marshall 2000:12; Parker 1983:38-9).

\section{LEGISLATION ON BURIALS}

The mythological first king of Athens, Cecrops, was traditionally believed to have instituted the original funeral rites (Cicero De Legibus. II.25-63). Plutarch (Lycurgus 27) claims that in about the $8^{\text {th }}$ century $\mathrm{BC}$ the legendary Lycurgus, king of Sparta, attempted to demythologise the process of death by approving burials within cities along with prominent funeral edifices in the vicinity of holy places. Corpses were to be buried simply in a red shroud, covered with olive leaves, and without funeral oblations. Except in the case of soldiers, names were not permitted to be carved on gravestones. The mourning period was also limited to eleven days, after which a sacrifice was to be offered to Demeter. Women were asked to lament loud and long at the graveside.

In contrast to this, later legislation took cognisance of the pollution of death. In general, legislators attempted to organise the burial procedure in a dignified manner but without causing inconvenience 
to the general public. The misuse of a funeral to attract attention (particularly for political reasons) was forbidden, as were extreme pomp and excessive expenditure (Garland 1989:1-3).

In the $6^{\text {th }}$ century BC, according to Demosthenes (Mac. 43.62), Cicero (Leg. II. 25.63) and Plutarch (Solon 21), Solon passed detailed laws which remained in force for a very long time and, according to Cicero, were later incorporated practically unchanged into the Roman Twelve Table Laws. In the main, these were rules for the preparation of the corpse indoors (prothesis), the pre-dawn funeral procession (ekphora), the burial and cremation ceremonies, the sacrifices at the grave, and the mourning process, as well as later visits to the grave. He did not specifically restrict the adornment of graves or mention the pollution of death in any detail, probably because the tradition for dealing with this was already solidly established. Later orators (Demosthenes Mac. 43.57-8) claim that he also passed regulations concerning corpses on the street and how to treat cases of death by suicide. It is possible that Solon instituted the Genesia (the annual festival of the dead on a particular day) in order to relieve the chaos caused by individual commemorations of the birthdays of the deceased at the gravesides (Garland 1989:4). Plutarch (Solon 12.8) also claims that at this time Epimenides took steps to limit the excessive lamentation of women because it was being exploited by opposing families and politicians (Garland 1989:3-5).

According to Cicero (Leg. II.64), Solon's laws were extended later in the $6^{\text {th }}$ century BC by legislation which, among other things, significantly limited the size of graves and their adornment. These post aliquando laws of about 530 BC (Kurtz \& Boardman 1971:121-41) were probably passed by Peisistratus (and later by Cleisthenes) and, among other things, forbade any constructions larger than ten workers could erect in three days. At about this time, painted terracotta plaques disappeared from graves; after $500 \mathrm{BC}$ these were followed by archaic memorial columns (stelai) (Garland 1989:5-7).

In the late $6^{\text {th }}$ century BC Charondes of Katana forbade excessive mourning at graves and suggested that this be replaced by joyous offerings of fruit (Garland 1989:8). In the $5^{\text {th }}$ century BC, in Delphi, a policy statement issued by the Labuade family forbade ostentatious 
Burial customs, the afterlife and pollution

funeral rituals, ordaining that processions should move quietly and without interruption to the grave; that mourning could take place only at the grave of the deceased itself, and that annual commemorations of the death should be restricted (Garland 1989:8-9). At about the same time, Solon's laws were reconfirmed at Iulis on Keos; the abuse of funeral arrangements for political or family purposes was forbidden; purification rituals were revised, and the triakosta (the festival of the thirtieth day) was abandoned (Garland 1989:11-13).

By 430 BC Attic memorial columns began to appear, followed in due course by larger and more ostentatious edifices on graves and extensive funeral rituals. In the late $4^{\text {th }}$ century BC, Demetrius of Phalerum passed laws which did not only restrict excesses at funerals as well as large grave structures, but also allowed for the appointment of special functionaries to impose fines. This bore fruit almost immediately (Cic. Leg. 2.60; Garland 1989:8).

In the $4^{\text {th }}$ century BC Plato (Leg. 958d-960c) refers to legislation on funerals which determines, among other things, that any uncertainty about sacred rites should be referred to a designated official for judgement; that graves could not be situated on agricultural land; that structures on graves could not be larger than five workers could erect in five days; that gravestones could include only four "heroic lines of inscription"; that the ekphora had to be orderly, and to have progressed outside the city walls by daybreak, and that special regulations would apply to the burials of suicides, murderers and other violent criminals, as well as to state funerals.

\section{FUNERAL RITES IN THE CLASSICAL ERA}

The Attic tradition, unlike that of the other Grecian city-states, was for its citizens to be buried at home. To forbid the burial of a citizen of Attica in his homeland was thus a very severe punishment (Kurtz \& Boardman 1971:142). However, and probably as a result of this general legislation, the literature contains few descriptions of specific burials, as Garland (1985:28) has shown. Archaeological discoveries and the study of relevant illustrations on the vases which were typically left at graves can tell us more. It was generally accepted that corpses - even those of enemies — should be properly buried. To neglect to 
perform this duty could expose one to divine punishment, although this fear had declined considerably by the Classical era (Parker 1983: 43-5). The typical funeral rites may be outlined as follows.

\subsection{Preparation of the body (prothesis)}

By law, the prothesis had to take place indoors, normally in the house of death. The body was washed, salved, clothed (typically in white or red material) (Parker 1983:3-5) and adorned with a crown, ribbons and flowers; jewels were seldom used. This task was usually performed by close female relatives over the age of sixty. Forms of mummification were known but seldom used (Garland 1985:34). The corpse was then placed on a bed made of planks (klinê) covered by a cloth (stroma), with the head on a pillow and the feet facing the door.

According to Plato (Leg. 959) the corpse was left in this position long enough (usually a day) to be sure that the person was indeed dead and to provide an opportunity for the traditional respects to be paid. Pictures on vases show us men approaching the corpse with their right hands raised, while women beat their heads and breasts. The women's lamentation was sometimes augmented by paid musicians (usually girls) who performed on the flute, harp and lyre at a set rate (Aristotle Athenian Constitution 50). Professional mourners (particularly Carian women) were discouraged.

Since the water in the house was considered to be polluted, a large jar of clean water from elsewhere was placed by the door so that the contaminated mourners could wash as they departed. This also warned passers-by that there had been a death in the house. Special branches or leaves do not appear to have been affixed for this purpose (Parker 1983:35).

\subsection{The funeral procession (ekphora)}

The corpse was usually carried to the grave outside the city walls before daybreak on the third day. Initially, this was done by family or friends (with a cart drawn by a horse or a mule), but later paid corpsebearers were hired. The corpse was covered with a cloth, except for the head, in accordance with the law. 
Burial customs, the afterlife and pollution

The cortège was to avoid main roads and not to stop on its way. The men accompanying it walked ahead, the women (who had to be close family members and over sixty years old) behind. There was no age restriction in respect of males. No lamentations or dirges were permitted (except in the case of official funerals) but, according to Solon, up to ten musicians (usually playing Carian music) could accompany the procession. Priests never attended, for fear of contamination (Parker 1983:36).

\subsection{The burial}

The burial ritual for a corpse (or for the ashes after cremation) was a simple one, and few detailed descriptions are available. In earlier times animal and even human sacrifices were made at the graveside. Homer (Il. 18.336-7), for example, describes how ten Trojan youths were sacrificed at the burial of Patroclus. The wives and horses of war heroes were also sometimes buried with them. There is evidence that this occurred occasionally even in the Classical era, although Solon had forbidden so much as the sacrifice of an ox (Garland 1985:34-6; Kurtz \& Boardman 1971:144-6).

The corpse was buried wrapped in a cloth, sometimes enclosed in a coffin. In the case of cremation, the ashes (in a container) were also buried in a grave. According to Cicero (Leg. II.25, 63), grain was traditionally strewn over the grave after it had been filled in. It is generally accepted that this could have formed part of the ta trita ceremony, which would be repeated three days later and was followed by the drinking (choê) and pouring of libations (spondai) for the gods. Gifts for the deceased were also left on or in the grave.

After this, the family would return to the house of death for a feast (perideipnon) commemorating the deceased's life and praising his deeds, which they would enjoy with great conviviality, wearing crowns and festive wreaths. Garland (1985:37) claims that the spirit of the deceased was believed to be present.

It is uncertain whether any other ceremonies took place at the grave on the third day, but it is known that the ta enata ritual (of which no details are known) occurred on the ninth day, followed by the triakosta ceremony on the thirtieth day. In Athens, this would end the period 
of mourning, but its duration varied from region to region (Kurtz \& Boardman 1971:149, 150). In parts of Greece (for example, the town of Iulis on Keos, where an inscription containing detailed regulations for funerals has been found) the triakosta ceremony was discontinued in the $5^{\text {th }}$ century BC (Garland 1985:40).

\subsection{Exceptional cases}

According to Plato (Leg. 909b \& c; Garland 1989:4), criminals were not buried after execution, but cast into the sea, into gravel pits or into wells. In the case of suicides, the right hand was chopped off before burial. If they had hanged themselves, the rope and branch (or whatever structure the rope had been attached to) were destroyed (Parker 1983:41, 42; Garland 1989:4). Slaves were entitled to a full burial and were often interred like members of the family. Their graves were simple, however, and no gifts were offered, because the popular conception was that slaves did not have an afterlife. There was no separate cemetery for them. Those who died as soldiers were normally buried with the same honours as their comrades. After the battles of Marathon and Plataea, however, soldiers of the slave class were buried separately (Kurtz \& Boardman 1971:198-9).

When an unknown corpse was found at the roadside, he would be buried by a civic official with the help of slaves (Arist. Ath. Const. 50.2).

\subsection{Purification and subsequent rites}

On the third day after the funeral, the house of death and the people contaminated by the death were purified. They would wash with unpolluted water (i.e. from a source other than the house). The house would be sprinkled with sea water, if possible, or with other unpolluted water, and strewn with soil. The procedure had to be performed by a free person. In Argos, "new fire" had to be brought from elsewhere before offerings could be made in the fireplace (Parker 1983:35; Marshall 2000:10).

According to Kurtz and Boardman (1971:149-51), the annual rites to commemorate the dead were viewed as extremely important — even more important than the ta trita and ta enata ceremonies. Unfortunately we have very little information about this, and the procedures 
also altered over time. At least seven different rites were performed at the graveside, sometimes on the birthday of the deceased, and sometimes on days fixed by legislation, including the Genesia, Nemesia, Nekusia and Epitaphia. These probably involved offerings of flowers, wreaths and ribbons, among other things, which would be placed on the graves with the utmost respect and reverence.

\section{GRAVES AND CEMETERIES}

In the $9^{\text {th }}$ and $8^{\text {th }}$ centuries BC, according to Kurtz and Boardman (1971:49-58), the deceased were buried both within and beyond the walls of Greek cities. (Research is complicated by uncertainty about the exact position of these walls.) After this period, graves were generally outside city walls, and by the $\sigma^{\text {th }}$ century $\mathrm{BC}$ this applied to all Athenian graves (Cicero Ad Familiares 4.12). In cities such as Sparta and Tarentum, however, burials still took place within the city walls even in the Classical era (Parker 1983:71).

In the Homeric era, cremation was more common than burial (Garland 1985:34). Graves were simple, rectangular pits for corpses or urns containing ashes. Cremations were performed elsewhere (which is described as secondary cremation). The sides of the graves were lined with tightly stacked stones or clay. Corpses, usually in shrouds rather than coffins, were covered over with a layer of stones or wooden beams. The corpses of children were usually placed in large clay pots. A heap of ground was piled over the closed grave, and sometimes a small stone dais was built. If a gravestone or wooden marker was provided, it was placed at the head of the grave in the case of a burial, or in the centre on top of the grave mound in the case of cremation. Large clay urns were sometimes left on graves, and gifts for the afterlife (food, clothes, jewellery, weapons, and even pets) were placed either in them or in special recesses next to them (Kurtz \& Boardman 1971:49-58).

The Archaic era (from the $8^{\text {th }}$ to the $6^{\text {th }}$ century BC) was characterised by an even greater preference for cremation, except in the case of children, who were buried directly. For the first time, cremations were regularly performed within the grave itself. Grave offerings continued and terracotta coffins began to be used but graves were no longer lined with stones. Grave mounds became much larger, and ornamental grave- 
stones and memorial columns became popular. As has been mentioned, this usage diminished after $530 \mathrm{BC}$, presumably due to legislation (Kurtz \& Boardman 1971:68-74).

During the Classical era (from the $4^{\text {th }}$ to the $3^{\text {rd }}$ century BC), cremation and burial were equally popular, but the literature still provides only insufficient descriptions of graves. Grave structures became simpler and more uniform; the incidence of cremation decreased markedly and it was performed less efficiently. In the grave, corpses were now often covered with "tents" of tiles piled at an angle rather than with layers of stone or wood, while metal containers were used instead of ceramic urns. Grave offerings now often included miniature arms made of clay, whose meaning is unclear. Grave coverings became larger and more complex until Demetrius of Phalerum's legislation forbade such ostentation. Group graves (perioboloi) became popular, and prominent state sepulchres for Attic soldiers, where ceremonies were performed annually, began to appear outside the walls of Athens (Thucydides II.6; Kurtz \& Boardman 1971:91-108).

\section{CONCLUSION}

In the four centuries under discussion the concept of the afterlife thus underwent significant alteration. Hades, in particular, changed from a dark world of the shades — where the souls of the dead continued to exist in a neutral fashion, without intellect or identity, and completely isolated from the living — to a much more pleasant place in which souls could have an almost "earthly" existence, making contact with one another and even, in special circumstances, with the living. From this understanding developed necromancy - a practice which, according to the Bible (I Sam. 28:7-14), had been practised by the Canaanites as early as the $10^{\text {th }}$ century BC. The idea of Elysium as a paradise for the deserving, although probably conceived of by Homer, developed only later. Initially, the deserving did not die, but were transported directly to Elysium. Only much later would all the dead first travel to Hades where a tribunal would sit in judgement, despatching the just to Elysium and the rest to Tartarus for eternal punishment. 
Against this background the role of the gifts which were left in the grave for the dead is uncertain (Kurtz \& Boardman 1971:206-209; 330-333). It was not apparently ever believed that the soul could take gifts with it on its journey to Hades, and only in the Classical era would Hermes be accorded the power to establish contact between souls in Hades and those on earth. (According to Lucianus, it was accepted that libations poured at graves could strengthen souls in Hades.) In the case of reincarnation such gifts would, in theory, be useful for the journey of the dead, but although certain philosophical groups such as the Orphists, Platonists and Pythagoreans believed in a form of reincarnation, this was never generally accepted (Rose \& Parker 1979:1089). Lucianus (On funerals 6-12) would later ridicule the concept of posthumous existence as well as the provision of gifts for the dead. One might ask whether the majority of Greeks in the Classical era actually still believed in the afterlife, or whether the ritual burial ceremonies, including the grave gifts, did not merely represent a somewhat sentimental show of respect for tradition and for the deceased, rather than any real religious conviction.

There has been much speculation about the origin and nature of the concept of pollution by death (Parker 1983:54-66; Garland 1985:457). It is clear that this notion, as held in the Classical era, was not known to Homer (Parker 1983:66-9). Warriors in his epic tales are not contaminated by contact with corpses, nor do the gods eschew scenes of death (Hom. Il. 23.52-3; 18.23-5). Hesiod does suggest such contamination when he counsels against sexual intercourse after a funeral ceremony (Works and days 735-6) but elsewhere in the $8^{\text {th }}$ century BC pollution is a physical, not a metaphysical issue. (Plutarch's contention that Lycurgus's legislation was an attempt to ban fear and superstition from the process of death $[L y c .27 .1]$ may indicate the existence of a concept of contamination which the Spartan king was specifically desirous of eliminating.) Between the 8 th and the $5^{\text {th }}$ century $\mathrm{BC}$ the pollution of death as a metaphysical, cultural/religious concept took firm root, however, and although Solon's laws of the early $6^{\text {th }}$ century BC do not specifically mention it, it is taken up in later funeral legislation, as has been shown. Fear of the hygienic complications associated with death may almost certainly be dismissed as a cause for this line of thought (Marshall 2000:8, 9, 16). These were 
simply accepted by participants as part of the funeral procedure, like wearing dark clothes, and no element of fear was implied (Parker 1983:35).

Garland (1985:45-7) considers the concept of pollution to have had a complex origin. He is not convinced by the theory that it was based on the idea of combating ancient demons, possibly linked to the goddess Hecate, who was associated with death. Moulinier (in Garland 1985:46) considers that a profound distaste for the morbid physical implications of death manifested itself on the metaphysical level in terms of concepts relating to pollution. Although Thucydides described in the $5^{\text {th }}$ century BC how epidemic diseases could spread from person to person (Retief \& Cilliers 1998:51), the concept of pollution did not involve considering the corpse as a source of disease. The fact that a corpse could be viewed in the Classical era, in certain circles at least, as a religious/sacred object would indeed have discouraged human contact with it, as sanctity is inappropriate to the human condition and thus a "contamination" (Garland 1985:146-7). Van Gennep (in Parker 1985:59-60) postulates that humanity has a tendency to create rituals to accompany all the important transitional periods of life and that death, as the final, irreversible process of transition to a future associated with the gods, was so ritualised that bystanders were viewed as temporarily distanced from the gods ("polluted"). According to Parker (1985:64), the Greeks believed that a temporary aura of sanctity from the deceased at the time of the departure to the afterlife (the process of death) also "contaminated" the next of kin and that they thus needed to be purified of this inappropriate "pollution" before they could continue with their everyday lives. One might ask, however, whether the average Greek in the Classical era would have had a fundamental understanding and acceptance of this concept of pollution, or whether it was not largely a legally-determined ritual which ensured the maintenance of an appropriate distance between humanity and the exalted divine powers during the process of death. 
Burial customs, the afterlife and pollution REFERENCES

\section{ARISTOTLE}

1935. Athenian constitution (transl. H. Rackham). Cambridge MA: Harvard University Press. Loeb Classical Library. Vol. XX.

\section{Cicero}

1928. On the laws (transl. C.W. Keyes). Cambridge MA: Harvard University Press. Loeb Classical Library. Vol XVI.

2001. Letters to his friends (transl. D.R. Shackleton Bailey). Cambridge MA: Harvard University Press. Loeb Classical Library. Vol. XXV.

\section{DEMOSTHENES}

1936. Private orations. Against Macartatus (transl. A.T. Murray). Cambridge MA: Harvard University Press. Loeb Classical Library. Vol. IV.

\section{GARLAND R}

1985. The Greek way of death. New York: Cornell University Press.

1989. The well-ordered corpse: an investigation into the motives behind Greek funeral legislation. Bulletin of the Institute of Classical Studies 36:1-15.

GRIMAL P (ED.)

1965. Larousse world mythology. New York: Prometheus Press.

\section{HERODOTUS}

1922. Histories (transl. A.D. Godley). Cambridge MA: Harvard University Press. Loeb Classical Library.

\section{HESIOD}

1973. Homeric hymns, Epic cycle, Homerica (transl. H.G. Evelyn-White). Cambridge MA: Harvard University Press. Loeb Classical Library.

\section{HOMER}

1995. The Odyssey (transl. A.T. Murray). Cambridge MA: Harvard University Press. Loeb Classical Library. Vols. I \& II.

1999. The Iliad (transl. A.T. Murray). Cambridge MA: Harvard University Press. Loeb Classical Library. Vols. I \& II.

KURTZ D C \& BOARDMAN J

1971. Greek burial customs. Thames \& Hudson: London.

\section{LUCIAN}

1925. On funerals et al (transl. A.M. Harmon). Cambridge MA: Harvard University Press. Loeb Classical Library. Vol. IV.

MARShaLl E

2000. Death and disease in Cyrene. In: V.M. Hope \& E Marshall (eds), Death and disease in the ancient city. London \& New York: Routledge. 
Acta Theologica Supplementum 7

MORFORd M P O \& LENARDON R J

1995. Classical mythology (5 $5^{\text {th }}$ ed.). New York: Longman.

PARKER R

1983. Miasma: pollution and purification in early Greek religion. Oxford: Clarendon Press.

\section{PLATO}

1026. Laws (transl. R.G. Bury). Cambridge MA: Harvard University Press. Loeb Classical Library. Vols. X \& XI.

1926. Greater Hippias et al. (transl. H.N. Fowler). Cambridge MA: Harvard University Press. Loeb Classical Library. Vol. IV.

\section{PLUTARCH}

1914. Lycurgus, Solon et al. (transl. B. Perrin). Cambridge MA: Harvard University Press. Loeb Classical Library. Vol I.

\section{Retief F P \& Cilliers L}

1998. The epidemic of Athens 430-426 BC. S.A. Medical Journal 88(1):50-53.

\section{ROWE C R}

1996. Transmigration. In S. Hornblower \& A. Spawforth (eds.), Oxford Classical Dictionary. Oxford: Clarendon Press. $3^{\text {rd }}$ ed.

\section{SOURVINOU-INWOOD C}

1995. "Reading" Greek death. Oxford: Clarendon Press.

\section{THUCYDIDES}

1928. History of the Peloponnesian War (transl. C.F. Smith). Cambridge MA: Harvard University Press. Loeb Classical Library. Vol. I. 